\title{
Development and Validation of a Stability-Indicating LC-UV Method for Simultaneous Determination of Ketotifen and Cetirizine in Pharmaceutical Dosage Forms
}

\author{
Prachi V Kabra $^{1 *}$, LVG Nargund ${ }^{1}$ and MS Murthy ${ }^{2}$ \\ ${ }^{1}$ Nargund College of Pharmacy, Dattatreyanagar, IInd Main, 100ft. Ring Road, BSK IIIrd Stage, Bangalore-560085, ${ }^{2}$ Vignan \\ Institute of Pharmaceutical Sciences, Vignan Hills, Deshmuki Village, Pochampally Mdl, Nalgonda District-508284, India
}

*For correspondence: Email: prachi.v.kabra@gmail.com

\begin{abstract}
Purpose: To develop and validate stability-indicating reversed phase high performance liquid chromatographic method for simultaneous determination of ketotifen fumarate and cetirizine dihydrochloride in solid dosage forms.

Methods: Chromatographic separation was achieved on Grace Smart C18 column $(250 \times 4.6 \mathrm{~mm}, 5$ $\mu \mathrm{m})$ using an isocratic mobile phase that consisted of acetonitrile and $10 \mathrm{mM}$ disodium hydrogen phosphate buffer ( $\mathrm{pH}$ 6.5) in a ratio of $45: 55 \% \mathrm{v} / \mathrm{v}$ at a flow rate of $1 \mathrm{~mL} / \mathrm{min}$. Detection was carried out at $230 \mathrm{~nm}$. Salbutamol sulphate was used as an internal standard. The drugs were exposed to hydrolytic (acid and alkaline), oxidative, reductive and neutral stress conditions, and the stressed samples analyzed by the proposed method. Validation of the method was carried out as per International Conference of Harmonization (ICH) guidelines.

Results: The retention time for ketotifen, salbutamol and cetirizine was 2.05, 5.37 and $6.77 \mathrm{~min}$, respectively. In stress studies, it was observed as cetirizine was more labile in acidic, oxidative and neutral conditions than ketotifen. Both the drugs were found comparatively stable in alkaline, neutral condition and labile in reductive condition. The method was linear in the concentration range of 1 - 30 $\mu \mathrm{g} / \mathrm{mL}$ and $10-300 \mu \mathrm{g} / \mathrm{mL}$ for ketotifen and cetirizine, respectively.

Conclusion: The developed method is specific and stability-indicating as no interfering peaks of degradants and excipients were observed. Thus, the method is suitable for application in the simultaneous quality control of both drugs.
\end{abstract}

Keywords: Ketotifen, Cetirizine, Stability indicating method, Stressed conditions, Validation

Tropical Journal of Pharmaceutical Research is indexed by Science Citation Index (SciSearch), Scopus, International Pharmaceutical Abstract, Chemical Abstracts, Embase, Index Copernicus, EBSCO, African Index Medicus, JournalSeek, Journal Citation Reports/Science Edition, Directory of Open Access Journals (DOAJ), African Journal Online, Bioline International, Open-J-Gate and Pharmacy Abstracts

\section{INTRODUCTION}

Asthma is a disorder that causes the airways of the lungs to swell and narrow, leading to wheezing, shortness of breath, chest tightness and coughing. An estimated three hundred million people worldwide suffer from asthma, with two hundred and fifty thousand $(250,000)$ annual deaths attributed to this disease. Workplace conditions, such as exposure to fumes, gases or dust are responsible for $11 \%$ of asthma cases worldwide. About $70 \%$ of asthmatics also have allergies. It is thought to be caused by a combination of genetic and environmental factors [1].

Ketotifen fumarate (KETO) is a relatively selective, non-competitive histamine antagonist (H1-receptor) and mast cell stabilizer [2]. Cetirizine dihydrochloride (CET), a human 
metabolite of hydroxyzine, is an antihistamine; its principal effects are mediated via selective inhibition of peripheral $\mathrm{H} 1$ receptors [3]. Chemical structure of KETO and CET is shown in Figure 1.
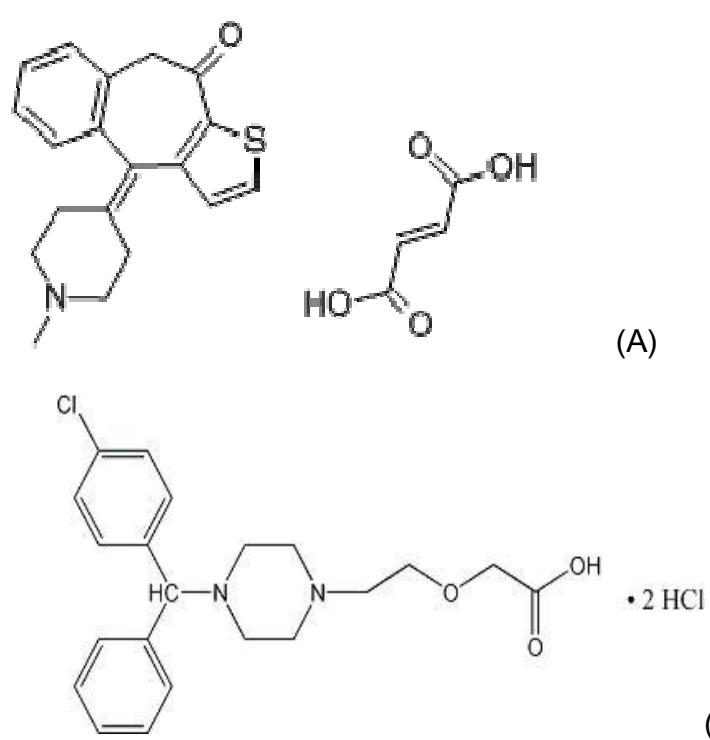

(B)

Figure 1: Chemical structure of (A) ketotifen fumarate and $(B)$ cetirizine dihydrochloride

Recently a combination of ketotifen and cetirizine is launched in the market which can be used as antihistamine and anti-allergics for the treatment of asthma and chronic urticaria. Chronic urticaria is a condition where an itchy rash persists on and off for six weeks or more [4].

Stability testing attempts to ensure the quality of the drug product not only during manufacturing, production and packaging even during storage till the patient consumes it. During the course of storage the drug product may get exposed to adverse environmental conditions such as extreme temperature, varying humidity and intense lights. Considering these aspects, many regulatory bodies including $\mathrm{ICH}$ [5] and $\mathrm{WHO}$ [6] framed specific guidelines to ensure the quality of the drug product during the storage conditions. This mainly involves exposing the drug product to adverse environmental conditions: acidic, basic, oxidative, reductive and neutral conditions and also to develop an analytical method for the estimation of active constituent or constituents in a pharmaceutical formulation in the presence of the degradants [7].

Literature survey revealed that few analytical methods are reported for the estimation of ketotifen alone or with other drugs. Spectrophotometric methods using multicomponent mode of the instrument [8], using $\lambda$ max of $298 \mathrm{~nm}$ when in methanol solution [9], colorimetric method [10], estimation based on ion pair formation [11] are available in literature. Several HPLC methods for estimation of ketotifen in pharmaceutical dosage form [12] and in biological fluids [13] are also reported. Stability indicating HPLC method is reported for ketotifen where drug is exposed to heat, oxidative media and UV light [14].

Various analytical methods such as spectrophotometric methods [15], HPLC method [16] and HPTLC methods [17] are reported for estimation of cetirizine alone or in combination with other drugs in pharmaceutical formulation. LC/MS/MS method is reported for estimation of cetirizine from human plasma using positive electrospray ionization method [18]. One stability-indicating HPLC method has been reported where the stability of cetirizine was checked at 40 and $50{ }^{\circ} \mathrm{C}$ at $75 \%$ relative humidity for six months [19].

No stability-indicating reversed phase HPLC method for simultaneous determination of ketotifen and cetirizine was found in literaure. Thus, the objective of the present work was to develop and validate a stability-indicating reversed phase HPLC method for the simultaneous determination of ketotifen and cetirizine in pharmaceutical formulations.

\section{EXPERIMENTAL}

\section{Materials}

KETO and CET were procured as gift samples from East West Pharma, Haridwar and Micro Labs Pvt. Ltd., Bangalore respectively. HPLC Grade acetonitrile, orthophosphoric acid and analytical grade disodium hydrogen phosphate buffer, hydrochloric acid, sodium hydroxide, hydrogen peroxide, sodium bisulphate were purchased from Merck, Mumbai. Mastifen-C Tablets (KETO-1 mg, CET-10 mg; East West Pharma, Haridwar) were purchased from local pharmacy.

\section{Chromatographic conditions}

Chromatographic separation was performed on Grace Smart C18 column $(250 \mathrm{~mm} \times 4.6 \mathrm{~mm}, 5$ $\mu \mathrm{m}$ ) using mobile phase consisted of acetonitrile $10 \mathrm{mM}$ disodium hydrogen phosphate buffer in proportion of $45: 55 \% \mathrm{v} / \mathrm{v}$ where $\mathrm{pH}$ of phosphate buffer was adjusted to 6.5 using $1 \%$ orthophosphoric acid. The mobile phase was filtered through $0.22 \mu \mathrm{m}$ Super 200 membrane 
filter and degassed in ultrasonic bath for $10 \mathrm{~min}$ before use. The flow rate was maintained at 1.0 $\mathrm{mL} / \mathrm{min}$ and wavelength of UV detector was set at $230 \mathrm{~nm}$.

\section{Preparation of standard solution}

Standard stock solution of KETO and CET (1 $\mathrm{mg} / \mathrm{mL}$ ) were prepared separately in the HPLC grade water and after suitable dilution these solutions were used for mobile phase optimisation and peak identification. For the construction of the calibration curve, a combined standard solution of KETO $(0.1 \mathrm{mg} / \mathrm{mL})$ and CET $(1 \mathrm{mg} / \mathrm{mL})$ was prepared in HPLC grade water. Further, this stock solution was diluted with mobile phase to a concentration in the range of 1 - $30 \mu \mathrm{g} / \mathrm{mL}$ for KETO and $10-300 \mu \mathrm{g} / \mathrm{mL}$ for CET, with $10 \mu \mathrm{g} / \mathrm{mL}$ of salbutamol sulphate (SAL) as an internal standard (IS).

\section{Instrumentation}

A Shimadzu HPLC system that consisted of an isocratic pump LC 20 AT, rheodyne injector (20 $\mu l)$ with SPD 20A UV visible detector was employed. HPLC data was processed using Spinchrome CFR software, version 2.1.4.93.

\section{Analysis of dosage form}

Twenty tablets of KETO and CET (Mastifen-C) were weighed and crushed to obtain fine powder. An accurately weighed tablet powder equivalent to about $2.5 \mathrm{mg}$ of KETO ( $25 \mathrm{mg}$ of CET) was transferred to $25 \mathrm{ml}$ volumetric flask. About $10 \mathrm{ml}$ of HPLC Grade water was added and the solution was sonicated for $15 \mathrm{~min}$. The volume was made up to the mark with the same solvent to get concentration of $100 \mu \mathrm{g} / \mathrm{mL}$ of KETO and $1000 \mu \mathrm{g} / \mathrm{mL}$ of CET. The resulting solution was filtered through Whatman filter paper no. 41. From this solution $1 \mathrm{~mL}$ of the aliquot was transferred to a $10 \mathrm{ml}$ volumetric flask along with this $1 \mathrm{~mL}$ of SAL solution $(100 \mu \mathrm{g} / \mathrm{mL})$ (IS) was added. The volume was made up to the mark with mobile phase to obtain a solution with final concentration of $10 \mu \mathrm{g} / \mathrm{mL}$ of KETO, $100 \mu \mathrm{g} / \mathrm{mL}$ of CET and $10 \mu \mathrm{g} / \mathrm{mL}$ of SAL. Similarly the combined standard stock solution, with IS was diluted in mobile phase to get the concentration of $10 \mu \mathrm{g} / \mathrm{mL}$ of KETO, $100 \mu \mathrm{g} / \mathrm{mL}$ of CET and 10 $\mu \mathrm{g} / \mathrm{mL}$ of SAL. Content of both the drugs present in tablet were analysed using single point analysis method using equation 1 .

$\mathrm{C} 1=\mathrm{R} 1(\mathrm{C} 2 / \mathrm{R} 2)$ where, C1 and C2 are concentration of sample and standard solutions, respectively, R1 = peak area ratio of drug to internal standard of sample solution, and R2 = peak area ratio of drug to internal standard of standard solution

\section{Forced degradation study}

In order to establish whether the developed analytical method was stability indicating, forced degradation of standard KETO and CET in combination was carried out under acid - base hydrolytic, oxidative, reductive and neutral conditions at $80^{\circ} \mathrm{C}$. As both the drugs are water soluble, solutions of $0.5 \mathrm{M} \mathrm{HCl}, 0.5 \mathrm{M} \mathrm{NaOH}, 3$ $\% \mathrm{H}_{2} \mathrm{O}_{2}$ and $1 \% \mathrm{NaHSO}_{3}$ were prepared in water. Both the drugs were dissolved in these solutions to achieve the concentration of 100 $\mu \mathrm{g} / \mathrm{mL}$ of KETO and $1000 \mu \mathrm{g} / \mathrm{mL}$ of CET. At specified time the samples of the reaction mixtures $(1 \mathrm{~mL})$ were withdrawn, cooled to room temperature and neutralized. To each sample, 1 $\mathrm{mL}$ of the internal standard, SAL $(100 \mu \mathrm{g} / \mathrm{mL})$ was added and the volume was made up to 10 $\mathrm{mL}$ with mobile phase to get concentration of 10 $\mu \mathrm{g} / \mathrm{mL}$ of KETO, $100 \mu \mathrm{g} / \mathrm{mL}$ of CET and 10 $\mu \mathrm{g} / \mathrm{mL}$ of $S A L$.

Acid and base hydrolysis was performed using $0.5 \mathrm{~N} \mathrm{HCl}$ and $0.5 \mathrm{~N} \mathrm{NaOH}$ respectively and refluxed at $80^{\circ} \mathrm{C}$ for $1 \mathrm{~h}$. Oxidative studies were performed in $3 \% \mathrm{H}_{2} \mathrm{O}_{2}$ and refluxed at $80^{\circ} \mathrm{C}$ for $30 \mathrm{~min}$. Reductive studies were carried out in 1 $\% \mathrm{NaHSO}_{3}$ and refluxed at $80{ }^{\circ} \mathrm{C}$ for $1 \mathrm{~h}$. For study in neutral solution, the drugs were dissolved in water and refluxed at $80^{\circ} \mathrm{C}$ for $10 \mathrm{~h}$.

\section{Method validation}

The analytical method was validated for various parameters according to $\mathrm{ICH}$ guidelines as follows.

\section{Linearity}

The linearity of the method was determined at ten concentration levels ranging from $1-30 \mu \mathrm{g} / \mathrm{mL}$ of KETO and $10-300 \mu \mathrm{g} / \mathrm{mL}$ of CET $(n=6)$. The peak area ratio of KETO to SAL vs KETO concentration and peak area ratio of CET to SAL vs CET concentration were plotted and observed for correlation coefficient.

\section{Limit of detection (LOD) and quantification (LOQ)}

The LOD and LOQ parameters were determined from the regression equation of KETO and CET. 
$\mathrm{LOD}=3.3 \mathrm{SD} / \mathrm{S}, \mathrm{LOQ}=10 \mathrm{SD} / \mathrm{S}$; where SD is the standard deviation of $\mathrm{Y}$-intercept and $\mathrm{S}$ is the average slope value.

\section{Accuracy}

Recovery studies were carried out by standard addition method by adding known amounts of KETO and CET (reference standard) to the preanalyzed sample at three different concentration levels, i.e., 80,100 , and $120 \%$ of assay concentration and \% recovery was calculated.

\section{Precision}

The precision of the method was determined by repeatability, intermediate precision (intra-day, inter-day, variation by different analyst) and expressed as \% relative standard deviation. Repeatability study was performed by analysing six times the same concentration of drugs (KETO $10 \mu \mathrm{g} / \mathrm{mL}$, CET $100 \mu \mathrm{g} / \mathrm{mL}$ ) while intra-day precision was determined by performing analysis of triplicate injections of three different concentration of combination of the drugs $(4,10$, $20 \mu \mathrm{g} / \mathrm{mL}$ of KETO and 40, 100, $200 \mu \mathrm{g} / \mathrm{mL}$ of CET) on the same day at different time intervals and three different days for inter-day precision. Variation of results by different analyst was studied by performing assay in triplicate by Analyst I and Analyst II and the results compared for significant difference by F-test and Students ttest.

\section{Robustness}

Robustness of the method was evaluated by varying experimental conditions ( $\pm 2 \%$ ) such as $\mathrm{pH}$, flow rate and organic phase content of the mobile phase. For each parameter change, its influence on the retention time, number of theoretical plates, tailing factor and resolution were evaluated.

Table 1: Assay results for tablet formulation

\section{RESULTS}

The retention time of KETO, SAL (IS) and CET were found to be 2.05, 5.37 and $6.77 \mathrm{~min}$, respectively. Chromatogram of the sample solution is shown in the Figure 2.

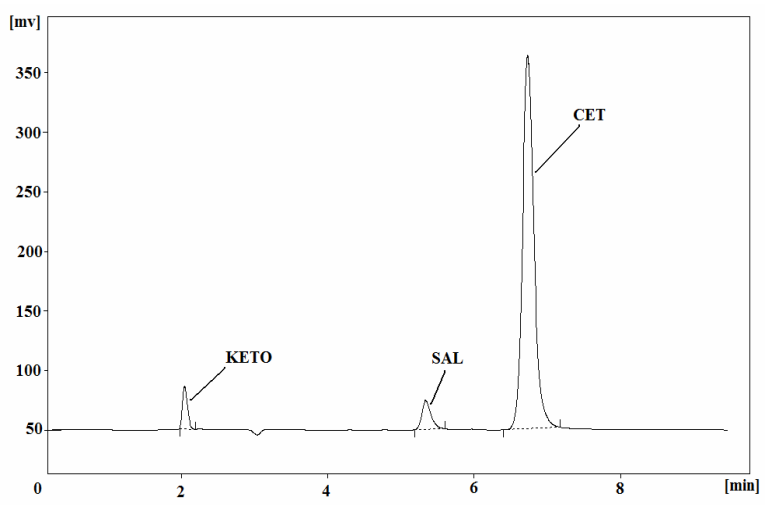

Figure 2: Chromatogram of sample solution

Amount of drugs present in the marketed formulation (Mastifen-C) were calculated using single point analysis method. Mean drug content was 99.43 and $100.50 \%$ for KETO and CET, respectively. The result of the assay of the tablet formulation is shown in Table 1.

The drugs were subjected to different stress conditions and the outcomes of stress studies are tabulated in Table 2.

\section{Linearity, LOD and LOQ}

The calibration plot was linear over the concentration range of $1-30 \mu \mathrm{g} / \mathrm{mL}$ for KETO and $10-300 \mu \mathrm{g} / \mathrm{mL}$ for CET $(\mathrm{n}=6)$ with RSD values $\leq$ $2.76 \%$, across the concentration range studied. The LOD values for KETO and CET were found as 0.13 and $1.60 \mu \mathrm{g} / \mathrm{mL}$ respectively. The LOQ values were observed as $0.40 \mu \mathrm{g} / \mathrm{mL}$ for KETO and $4.85 \mu \mathrm{g} / \mathrm{mL}$ for CET. Results system suitability and linearity data for the proposed method is shown in Table 3.

\begin{tabular}{lcccccc}
\hline S/N & \multicolumn{2}{c}{ Claimed amount $(\mathrm{mg} / \mathrm{tab})$} & \multicolumn{2}{c}{ Amount found $(\mathbf{m g} / \mathrm{tab})$} & \multicolumn{2}{c}{ Actual strength (\%) } \\
& KETO & CET & KETO & CET & KETO & CET \\
\hline 1 & 1 & 10 & 0.9965 & 9.9985 & 99.65 & 99.99 \\
2 & 1 & 10 & 0.9904 & 10.1101 & 99.04 & 101.10 \\
3 & 1 & 10 & 0.9994 & 10.0424 & 99.94 & 100.42 \\
4 & 1 & 10 & 0.9918 & 10.0333 & 99.18 & 100.33 \\
5 & 1 & 10 & 0.9936 & 10.0261 & 99.36 & 100.26 \\
6 & 1 & 10 & 0.9938 & 10.0886 & 99.38 & 100.89 \\
Mean & & & 0.9943 & 10.0498 & 99.43 & 100.50 \\
$\mathbf{I}$ SD & & 0.00326 & 0.0416 & 0.3259 & 0.4161 \\
\%RSD & & 0.3278 & 0.4141 & 0.3278 & 0.4141 \\
\hline
\end{tabular}


Table 2: Results of forced degradation studies

\begin{tabular}{|c|c|c|c|c|}
\hline \multirow[t]{3}{*}{ Stress condition } & \multicolumn{4}{|c|}{ Degradation (\%) } \\
\hline & \multicolumn{2}{|c|}{ Standard } & \multicolumn{2}{|c|}{ Sample } \\
\hline & KETO & CET & KETO & CET \\
\hline Acidic/0.5 M HCl/1h $/ 80^{\circ} \mathrm{C}$ & 7.519 & 29.896 & 17.037 & 29.436 \\
\hline Basic/0.5 M NaOH/1h /80 C & 11.545 & 3.971 & 10.789 & 9.182 \\
\hline Oxidative $/ 3 \% \mathrm{H}_{2} \mathrm{O}_{2} / 30 \mathrm{~min} / 80^{\circ} \mathrm{C}$ & 0.293 & 30.007 & 3.516 & 29.630 \\
\hline Reductive $/ 1 \% \mathrm{NaHSO}_{3} / 1 \mathrm{~h} / 80^{\circ} \mathrm{C}$ & 29.138 & 29.898 & 29.875 & 26.357 \\
\hline Neutral $/ \mathrm{H}_{2} \mathrm{O} / 10 \mathrm{~h} / 80^{\circ} \mathrm{C}$ & 12.710 & 25.245 & 14.016 & 29.285 \\
\hline
\end{tabular}

Table 3: System suitability and linearity data for the proposed method

\begin{tabular}{lll}
\hline Parameter & KETO & CET \\
\hline Retention time $(\min )(\% \mathrm{RSD})$ & $2.05(0.20)$ & $6.77(0.19)$ \\
Tailing Factor $(\% \mathrm{RSD})$ & $1.52(1.46)$ & $1.42(1.59)$ \\
Plate Count $((\% \mathrm{RSD})$ & $4210(1.76)$ & $11557(1.89)$ \\
Linearity and Range $(\mu \mathrm{g} / / \mathrm{mL})$ & $1-30$ & $10-300$ \\
Slope $( \pm \mathrm{SD})$ & $0.090(0.0007)$ & $0.209(0.0009)$ \\
Intercept $( \pm \mathrm{SD})$ & $0.0059(0.0036)$ & $0.693(0.101)$ \\
Correlation Coefficient & 0.9999 & 0.9995 \\
LOD $(\mu \mathrm{g} / \mathrm{mL})$ & 0.13 & 1.60 \\
$\mathrm{LOQ}(\mu \mathrm{g} / \mathrm{mL})$ & 0.40 & 4.85 \\
\hline
\end{tabular}

\section{Accuracy and precision}

Percent recovery of KETO and CET was in the range from 98.77 - $99.62 \%$ and 99.39 - 100.41 $\%$, respectively. Precision of the method was determined by \% RSD found among intra-day precision, inter-day precision, repeatability. It was found to be less than $1 \%$.Variation of results by two different analyst was determined by preparing and measuring the sample solutions of KETO $(10 \mu \mathrm{g} / \mathrm{mL})$ and CET $(100 \mu \mathrm{g} / \mathrm{mL})$ by Analyst 1 and Analyst 2, separately. The values obtained were evaluated using F-test and t-test to verify their precision. Calculated value for ttest was 0.5748 for KETO and 0.0185 for CET, which are less than the tabulated or standard value (1.533), and hence no significant difference was observed between the results of the two analysts at a probability value of 0.10 . The results of recovery study are shown in Table 4 while the results of variation by the two analysts are given in Table 5.

\section{Robustness}

For robustness study, the effect of change in the $\mathrm{pH}(2 \%)$ of mobile phase, organic phase ratio (2 $\%)$ and flow rate $(2 \%)$ on the retention time, asymmetry factor, theoretical plates and resolution were studied. Combined standard solutions of KETO $(10 \mu \mathrm{g} / \mathrm{mL})$, CET $(100 \mu \mathrm{g} / \mathrm{mL})$ and $\mathrm{SAL}(10 \mu \mathrm{g} / \mathrm{mL})$ were prepared and analyzed at different $\mathrm{pH}(6.37,6.5,6.63)$ of the mobile phase, at different organic phase ratio $(44.1: 55.9,45: 55,45.9: 54 ; 1 \% \mathrm{v} / \mathrm{v})$ and at different flow rate $(0.98,1.0,1.02 \mathrm{~mL} / \mathrm{min})$. Percentage RSD of retention time, tailing factor, number theoretical plates and resolution of peak in all three variables was found to be less than 5 $\%$.

Table 4: Results of recovery study

\begin{tabular}{lll}
\hline DRUG & $\begin{array}{l}\text { Amount added } \\
(\boldsymbol{\mu g} / \mathrm{mL})\end{array}$ & $\begin{array}{l}\text { \% Recovery, } \\
\text { \%RSD }\end{array}$ \\
\hline KETO & 08 & $99.40,0.016$ \\
& 10 & $99.05,0.258$ \\
CET & 12 & $99.48,0.114$ \\
& 10 & $99.39,0.013$ \\
& 120 & $99.92,0.164$ \\
\hline
\end{tabular}

\section{DISCUSSION}

All reported methods for KETO and CET as individual drug or in combination with other drugs, used C8 and C18 column as a stationary phase. Hence attempts were directed towards development of chromatographic method on

Table 5: Results of variation by different analyst

\begin{tabular}{llllll}
\hline Drug & \multicolumn{2}{l}{ (\% Drug content* ${ }^{\star}$ SD) } & F-test value & t-test value & Inference \\
\cline { 2 - 6 } & Analyst 1 & Analyst 2 & & & \\
\hline KETO & $99.54 \pm 0.460$ & $99.30 \pm 0.108$ & 0.0557 & 0.5748 & No significant difference \\
CET & $100.50 \pm 0.562$ & $100.49 \pm 0.341$ & 0.3701 & 0.0185 & No significant difference \\
\hline
\end{tabular}


commonly used C18 column for simultaneous estimation of the prescribed drugs. To optimize mobile phase composition for KETO and CET, different proportions of the mobile phase at different $\mathrm{pH}$ were tested. Considering the $\mathrm{pKa}$ value of KETO (8.43) and CET (1.6, 2.9, 8.3), different $\mathrm{pH}$ values of the mobile phase were tried in the range of 4.0 to 6.5. Final decision on the mobile phase composition and flow rate was done on the basis of peak area, resolution between the peaks of the drug and their degradation products, tailing factor, number of theoretical plates and time required for the analysis. The chromatographic conditions were finally optimized on Grace Smart C18 Column $(250 \times 4.6 \mathrm{~mm}, 5 \mu \mathrm{m})$ using $1 \mathrm{~mL} / \mathrm{min}$ flow rate of $45: 55 \% \mathrm{v} / \mathrm{v}$ of acetonitrile: $10 \mathrm{mM}$ disodium hydrogen phosphate buffer solution $(\mathrm{pH} 6.5$ adjusted with $1 \%$ ortho-phosphoric acid) as mobile phase. An analytical wavelength was selected considering the good absorbance of both the prescribed drug and IS. Hence, detection was done at $230 \mathrm{~nm}$ where all the drugs showed absorbance. Under these conditions the peak of KETO and CET were well defined and free from tailing.

Preliminary trials on the individual drugs and in combination were conducted to optimize various stress conditions. Conditions used for the stress studies were attenuated to achieve degradation in the range of $10-30 \%$ for establishing stability indicating nature of the method. Samples were withdrawn at different time intervals, to monitor rate of degradation and the stress conditions were optimized. It was observed that, CET is more labile in acidic, oxidative and neutral conditions as compared to KETO. CET was found to be degrading after $4 \mathrm{~h}$ of heating in 0.1 $\mathrm{N} \mathrm{HCl}$ but KETO showed insufficient degradation under the same condition, hence further stress studies for drug combination were performed in $0.5 \mathrm{~N} \mathrm{HCl}$. Both the drugs were found comparatively stable in alkaline condition and labile in reductive condition. Degradation of both the drugs were found to be extensive in $2.5 \%$ of sodium bisulphate $\left(\mathrm{NaHSO}_{3}\right)$, hence further study was done in $1 \%$ of $\mathrm{NaHSO}_{3}$. Rapid degradation was observed when CET was exposed to $3 \% \mathrm{H}_{2} \mathrm{O}_{2}$ as compare to KETO. Hence, it was refluxed only for 30 min. Blank oxidative reagent, i.e., $3 \% \mathrm{H}_{2} \mathrm{O}_{2}$ showed a peak at $2.9 \mathrm{~min}$, hence, it was not considered a degradant peak. Both drugs were stable in neutral conditions and therefore, the drugs were heated for $10 \mathrm{~h}$ to obtain a sufficient level of degradation.

\section{CONCLUSION}

Stability-indicating reversed phase HPLC method for simultaneous estimation of KETO and CET has been developed and validated. The method is specific and stability-indicating. The proposed method has ability to separate the two drugs and their degradation products and common excipients used in tablet dosage forms. Thus, it can be applied to the analysis of routine quality control samples as well as samples obtained in stability studies.

\section{ACKNOWLEDGEMENT}

The authors are grateful to East West Pharma, Haridwar and Micro Labs Ltd, Bangalore, India for providing ketotifen and cetirizine pure samples free of charge, and to Nargund College of Pharmacy, Bangalore for providing laboratory and research facilities for this work.

\section{REFERENCES}

1. American academy of allergy asthama \& immunology [home page on internet] asthama statistics [cited 2011 Nov 15]. Available from http://www.aaaai.org/ about-the-aaai/newsroom/asthama-statistics. aspx

2. Drug bank [home page on internet] Ketotifen [cited 2011 Nov 15]. Available from http://www.drugbank.ca/ drugs/DB00920

3. Drug bank [home page on internet] Cetirizine [cited 2011 Nov 15]. Available from http://www.drugbank.ca/ drugs/DB00341

4. Patient.co.uk [home page on internet] Chronic Urticaria (Hives) [cited 2011 Nov 24]. Available from http://www.patient.co.uk/health/chronic-urticaria-hives

5. $\mathrm{ICH}$, Stability Testing of New Drug Substances and Products. International Conference on Harmonisation, IFPMA, Geneva, 1993.

6. WHO, Guidelines for Stability Testing of Pharmaceutical Products Containing Well Established Drug Substances in Conventional Dosage Forms, in WHO Expert Committee on Specifications for Pharmaceutical Preparations. Technical Report Series 863, World Health Organization, Geneva, 1996, pp. 65-79.

7. Bakshi M, Singh S. Development of validated stability indicating assay methods: critical review. J Pharm Biomed Anal 2002; 28: 1011-1040.

8. Singh SV, Kabra $P$, Kimbahune $R$, Ghale $S$, Karwa $P$, Nargund LVG. Spectrophotometric estimation of ketotifen and salbutamol by validated analytical method from tablet dosage form. J Chem Pharm Res 2013; 5: 123-127.

9. Murlidharan S, Han LB, Ming JLY, Kartigayam S, Awang J, Dhanaraj SA. Development of spectrophotometry 
method for the estimation of ketotifen fumarate in bulk and in pharmaceutical tablet dosage form. Der Pharmac Lettre 2012; 4: 1339-1343.

10. Shinghvi I, Sachdeva D. Spectrophotometric estimation of ketotifen fumarate from tablet formulation. Ind. $J$ Pharm Sci 2009; 71: 66-68.

11. Al-Khazrajy OS. Spectrophotometric determination of ketotifen fumarate in pure and pharmaceutical preparations by bromophenol blue reagent. J Pure Appl Sci 2011; 24: 168-178.

12. Elaysed MMA. Development and validation of a rapid HPLC method for the determination of ketotifen in pharmaceuticals. Informa Healthcare 2006; 32: 457461.

13. Alali $F Q$, Tashtoush B M, Najib NM. Determination of ketotifen in human plasma by LC-MS. J Pharm Biomed Ana 2004; 34: 87-94.

14. Nane IP, Damani LA, Hutt AJ. Development and validation of stability indicating high performance liquid chromatographic assays for ketotifen in aqueous and silicon oil formulations. Chromatographia 1998; 48: 797-802.

15. Trivedi A, Banerjee L. Development of modified spectrophotometric and HPLC method for simultaneous estimation of ambroxol hydrochloride and cetirizine hydrochloride in tablet dosage form. $J$ Pharm Res 2010; 3: 1398-1401.

16. Lakshmi S, Lakshmi KS. Reverse phase - high performance liquid chromatographic method for the analysis of paracetamol, cetirizine and pseudoephedrine from tablets. Der Pharma Chemica 2009; 1: 37-46.

17. Dongale PS, Sahare SJ, Dhongale SS, Mundhey AS, Wate SP. Development and validation of HPTLC method for simultaneous estimation of cetirizine hydrochloride and phenylpropanolamine hydrochloride in tablet dosage form. Der Pharmacia Lettre 2011; 3: 111-119.

18. MA M, Feng F, Sheng Y, Cui S, Liu H. Development and evaluation of an efficient HPLC/MS/MS method for the simultaneous determination of pseudoephedrine and cetirizine in human plasma : Application to Phase-I pharmacokinetic study. J Chromatogra B 2007; 846: 105-111.

19. Khan MI, Murtaza G, Awan S, Mohammad I, Mhommad $K W$, Rasool A. Development and validation of stability indicating assay method cetirizine hydrochloride by HPLC. Afr. J. Pharm Pharmacol 2011; 5: 143-159. 